\title{
Performa berahi sapi PO pada berbagai BCS yang disinkronisasi dengan medroxy progesteron acetate di Satker Sumberejo Kendal
}

\author{
Muhammad Jamaluddin Ma'ruf, Edy Kurnianto dan Sutiyono \\ Fakultas Peternakan dan Pertanian Universitas Diponegoro, Semarang \\ Correspondence author: uddienjamal@gmail.com
}

\begin{abstract}
The objective of this study was to evaluate estrus appearance of Ongole crossbred cattle on various Body Condition Score synchronized with medroxy progesterone acetate. The material used in this study was 68 head female Ongole Grade cattle and classified into 3 based on BCS, that was low $(1-<4)$, middle $(\geq 4-<7)$, high $(\geq 7)$. Parameters of the study were number of cattle showing estrus, an appearance of vulva, mucus, uterus erection, speed, and length of estrus. Collecting data was done since the synchronization was stopped and estrus detection was done at $8 \mathrm{am}, 2 \mathrm{pm}$, and $7 \mathrm{pm}$ on 10 days. Data of this study was analyzed by descriptive mode and independent t-test. The result showed that cattle showing estrus in the group of BCS $1-<4, \geq 4-<7$ and $\geq 7$ were $32 \%, 35 \%$, and $40 \%$, respectively. The mode of color and temperature changing on BCS $1-<4, \geq 4-<7$ and $\geq 7$ were $+(100 \%)$; vulva swelling each group was $+(100 \%),+(77,78 \%),+$ and $-(50 \%)$, respectively, mode of mucus all of groups were $+(100 \%)$, while uterus erection at each group of BCS were $+(100 \%),+(77,78 \%)$ and $+(100 \%)$. Average of estrus speed on BCS 1$<4, \geq 4-<7$ and $\geq 7$ were $364,6 \pm 117,65,312,89 \pm 118,01$ and $372 \pm 220,62$, while estrus length BCS $1-<4, \geq 4-<7$ and $\geq 7$ were $628,71 \pm 61,43,533 \pm 190,19$ and $422 \pm 121,62$. In conclusion, estrus synchronization did not give significant effect on various cows BCS groups. The variety of BCS cows showing lust marks with almost the same intensity but moderate BCS is having a better lust than low and high BCS. Low BCS has better lust speed than moderate and high BCS.
\end{abstract}

Keywords: Ongole Grade Cattle, Body Condition Score, Reproduction, Estrus Intencity

\section{PENDAHULAN}

Kebutuhan masyarakat terhadap produk hewani khususnya daging meningkat setiap tahun, tetapi produksi daging belum mencukupi kebutuhan. Konsumsi daging dari tahun 1993 sampai dengan 2014 meningkat dari 0,704 $\mathrm{kg} / \mathrm{kapita} / \mathrm{tahun} \quad$ menjadi 2,36 $\mathrm{kg} / \mathrm{kapita} / \mathrm{tahun}$ (Kementan, 2015) dengan kebutuhan daging nasional mencapai
552.400 ton pada tahun 2013 (Badan Ketahanan Pangan, 2015). Berdasarkan data BPS (2016) produksi daging dalam negeri tahun 2012, 2013, 2014 adalah 508.906, 504.818, 497.670 ton. Sehingga kekurangan daging pada tahun 2013 sebesar17.582 ton $(8,6 \%)$ dan dicukupi dari daging impor.

Budidaya sapi yang banyak dilakukan oleh peternakan besar maupun 
oleh peternak rakyat di Indonesia adalah sapi Peranakan Ongole (PO), tetapi hanya sedikit peternak yang melakukan pembibitan sapi PO sehingga ketersediaan bakalan di pasaran terbatas. Peningkatan produksi bibit ternak perlu dilakukan pada sapi betina yang status reproduksinya kosong, dengan cara sinkronisasi berahi dan inseminasi buatan. Sinkronisasi berahi pada ternak dapat dilakukan dengan menggunakan berbagai macam hormon diantaranya adalah hormon prostaglandin, estrogen dan progesterone (Rizal, 2005) dan sapi yang berahi diinseminasi menggunakan semen beku sapi PO unggul.

Pusat pembibitan sapi Potong di Jawa Tengah yang berkonsentrasi pada sapi PO salah satunya adalah Balai Pembibitan Ternak Ruminansia Satuan kerja (BPTR Satker) Kendal. Permasalahannya pembibitan di Satker Sumberejo Kendal kurang berkembang, dikarenakan kekurangan pakan secara kualitas dan kuantitas, sehingga Body Condition Score (BCS) sapi induk kurang memenuhi standar BCS sapi yang dapat bereproduksi dengan baik.

Maka perlu dilakukan penelitian yang bertujuan untuk mengetahui penampilan berahi induk sapi PO berbagai BCS yang disinkronisasi berahi dengan Medroxy Progesterone Asetat di Satker Sumberejo Kendal. Manfaat hasil penelitian dapat digunakan sebagai dasar seleksi sapi PO indukan yang baik dan reproduktif, sehingga dapat digunakan sebagai dasar perbaikan penampilan reproduksi pada program pembibitan ternak.

\section{MATERI DAN METODE}

\section{Lokasi}

DOI: 10.21776/ub.jiip.2017.027.02.05
Penelitian dilakukan dengan metode observasi di Balai Pembibitan Ternak Ruminansia SATKER Sumberejo Kendal terutama dalam bidang reproduksi sapi. Penelitian dilaksanakan pada bulan Juni-Juli 2016.

\section{Materi}

Materi yang digunakan dalam penelitian ini adalah sapi PO betina sebanyak 68 ekor, sudah dewasa tubuh, tidak dalam keadaan bunting dengan status gigi poel 1 sampai 4 dengan nilai BCS 1 sampai 9 yang dibagi menjadi 3 kelompok yaitu: BCS 1-<4 sebanyak 31 ekor, BCS $\geq 4-<7$ sebanyak 32 ekor dan $\mathrm{BCS} \geq 7$ sebanyak 5 ekor.

Bahan yang digunakan dalam penelitian adalah spons vagina yang mengandung 50mg medroxy progesterone acetate (MPA), betadine salep, v-gell, alkohol. Alat yang digunakan dalam penelitian ini adalah spuit, aplikator, kertas tissue, senter, wearpack dan boots, tabel pengamatan.

\section{Metode}

Sinkronisasi berahi dilakukan dengan memasukkan spons vagina dalam vagina sapi. Pemasangan spons diawali dengan mengolesi spons dengan betadine salep sebagai pencegahan perkembangan mikroorganisme didalam vagina. Kemudian spon vagina dimasukan kedalam aplikator yang telah disterilkan dengan alkohol. Aplikator dilapisi v-gell pada bagian luar. Spons dimasukan kedalam vagina sampai kira-kira aplikator masuk $3 / 4$ bagian kemudian aplikator dicabut dan tali pada spons di sisakan sedikit menjuntai keluar untuk memudahkan proses pencabutan spons. Spons vagina dicabut pada hari ke-17 setelah pemasangan. 


\section{Parameter penelitian}

Parameter yang diamati adalah penampilan berahi sapi yang dilakukan setiap jam 08:00 WIB, 14:00 WIB dan 19:00WIB yang dilakukan selama 10 hari setelah pencabutan spons. Parameter tersebut meliputi:

1. Warna Vulva : skoring ada perubahan warna $(+)$ atau tidak ada perubahan warna (-) pada vulva.

2. Pembengkakan Vulva : skoring ada pembengkakan (+) atau tidak ada pembengkakan (-) yang terjadi pada vulva, dengan dilihat dan dilakukan palpasi

3. Perubahan Suhu Vulva : skoring ada perubahan (+) atau tidak ada prubahan suhu (-) pada vulva, dengan cara palpasi.

4. Munculnya Lendir : skoring ada lendir (+) atau tidak ada lendir (-) yang muncul/ keluar.

5. Ereksi Uterus : skoring berdasarkan ada ereksi uterus (+) atau tidak ada ereksi uterus (-) dengan cara palpasi rektal oleh inseminator yang bertugas.

6. Kecepatan Munculnya Berahi dihitung dengan mengamati, waktu pencabutan spons dan wktu munculnya berahi pertamakali, kemudian dihitung dengan rumus : $\mathrm{K}=\mathrm{A}-\mathrm{S}$

Keterangan :

$$
\begin{array}{llr}
\text { K } & \text { : Kecepatan Berahi } \\
\text { AB } & \text { : Waktu Muncul Berahi } \\
& \text { Pertama (jam/menit) } \\
\text { S } & \text { : Waktu } & \text { Pencabutan } \\
& \text { Spons } & \text { Vagina } \\
& \text { (jam/menit) } &
\end{array}
$$

7. Lama Berahi dihitung dengan mengamati waktu munculnya berahi pertamakali dan waktu berahi tidak muncul samasekali, kemudian dihitung dengan rumus: $\mathrm{L}=\mathrm{AB}-\mathrm{HB}$

Keterangan :

$$
\text { L : Lama Berahi }
$$
AB : Waktu Muncul Berahi Pertama (jam/menit)
HB : Tanda Berahi Hilang (jam/menit)
Analisis data terhadap perubahan warna, kebengkakan, perubahan suhu vulva, munculnya lendir dan ereksi uterus analisis menggunakan statistic deskriptif berdasarkan modus. Modus merupakan nilai yang mempunyai kemunculan dengan frekuensi paling besar, atau dapat dikatakan sebagai nilai yang sering muncul (Spiegel. 2004). Data kecepatan berahi dan lama berahi dianalisis menggunakan independen t-test.

Rumus uji independen t-tes :

$$
\mathrm{t}=\frac{\left.\overline{\left[\mathrm{X}_{1}\right.}-\overline{\mathrm{X}_{2}}\right]}{\mathrm{Se}}
$$

$$
\sqrt{\sqrt{\frac{\left[\sum_{i=1}^{n} \mathrm{X}_{11}^{2}-\frac{1}{n_{1}}\left(\sum_{i=1}^{n} \mathrm{X}_{11}\right)^{2}\right]+\left[\sum_{i=1}^{n} \mathrm{X}_{21}^{2}-\frac{1}{n_{2}}\left(\sum_{i=1}^{n} \mathrm{X}_{1} \hat{i}^{2}\right]+\right.}{n_{1}+n_{2}-2}\left(\frac{1}{n_{1}}+\frac{1}{n_{2}}\right)}}
$$

$$
\begin{array}{cl}
\text { Keterangan } & : \\
\mathrm{t} & \text { : nilai t hitung } \\
\overline{\mathrm{X}}_{1} & \text { : rata-rata sampel kelompok } 1 \\
\overline{\mathrm{X}}_{2} & \text { : rata-rata sampel kelompok } 1 \\
\mathrm{Se} & \text { : standar deviasi sampel } \\
\mathrm{n}_{1} & \text { : jumlah sampel kelompok } 1 \\
\mathrm{n}_{2} & \text { : jumlah sampel kelompok } 2 \\
& \text { Shinjo (1990). }
\end{array}
$$

\section{HASIL DAN PEMBAHASAN}

\section{Berahi}

Hasil pengamatan jumlah ternak yang menunjukkan berahi pada sapi PO yang disinkronisasi berahi menggunakan medroxy progesterone acetat disajikan dalam Tabel 1.

DOI: 10.21776/ub.jiip.2017.027.02.05 
Tabel 1. Jumlah Berahi dan Tidak Berahi, Status reproduksi dan Endometritis pada Sapi Hasil Sinkronisasi Berahi Sapi Berbagai BCS

\begin{tabular}{ccccccc}
\hline \hline & & & \multicolumn{4}{c}{ Sapi berahi * } \\
\cline { 3 - 5 } BCS & $\begin{array}{c}\text { Jumlah } \\
\text { Sapi }\end{array}$ & $\begin{array}{c}\text { Jumlah Sapi } \\
\text { Tidak Berahi }\end{array}$ & Jumlah & \multicolumn{2}{c}{$\begin{array}{c}\text { Keterangan } \\
\text { beranak }\end{array}$} & Endometritis \\
\cline { 4 - 5 } & & $15(68)$ & $7(32)$ & $1(14,3)$ & $6(85,7)$ & $1(14,1)$ \\
$1-<4$ & 22 & $17(65)$ & $9(35)$ & $1(11,1)$ & $8(88,9)$ & $3(33,33)$ \\
$\geq 4-<7$ & 26 & $3(60)$ & $2(40)$ & $1(50)$ & $1(50)$ & $-\quad(0)$ \\
\hline 7 & 5 & dara &
\end{tabular}

*) Dilihat dari jumlah sapi yang berahi, angka adalam kurung menyatakan \%

Persentase jumlah sapi berahi paling rendah adalah $\mathrm{BCS} 1-<4$, hasil tersebut menunjukan bahwa BCS rendah mengindikasikan bahwa ternak kekurangan nutrisi, sehingga mengakibatkan produksi hormon untuk pembentukan folikel terhambat dan berpengaruh pada kemunculan estrus. Hardjopranjoto (1995) menyatakan bahwa kekurangan nutrisi akan berakibat pada penurunan fungsi kelenjar dalam tubuh, salah satunya adalah hipofisa anterior sehingga terjadi penurunan sekresi hormon gonadotropin yaitu FSH dan LH. Sodiq dan Budiono (2012) menyatakan bahwa BCS dapat digunakan untuk menggevaluasi kecukupan nutrisi dan lemak yang dimiliki induk, sehingga nilai BCS sangat berpengaruh terhadap kemunculan estrus. Penyakit berupa endometritis diduga menjadi penyebab lain sehingga tidak terjadi berahi. Ratnawati et al. (2007) menyatakan bahwa endometitis merupakan peradangan pada dinding uterus akibat kontaminasi mikroorganisme yang berakibat pada fertilitas berupa penurunan kesuburan dalam jangka pendek dan dalam angka panjang dapat mengakibatkan kemajiran akibat perubahan saluran reproduksi.

\section{Penampakan vulva}

Data penampakan vulva Sapi PO berbagai BCS yang disinkronisasi berahi menggunakan medroxy progesterone acetat disajikan dalam Tabel 2.

Tabel 2. Modus Penampakan Warna, Kebengkakan dan Hangat pada Vulva Berbagai BCS Sapi Yang Berahi

\begin{tabular}{cccccccc}
\hline \hline \multirow{2}{*}{ BCS } & Jumlah & \multicolumn{2}{c}{ Merah } & \multicolumn{2}{c}{ Bengkak } & \multicolumn{2}{c}{ Hangat } \\
\cline { 2 - 7 } & sapi & modus & $\%$ & modus & $\%$ & modus & $\%$ \\
\hline $1-<4$ & 7 & + & 100 & + & 100 & + & 100 \\
$\geq 4-<7$ & 9 & + & 100 & + & 77,78 & + & 100 \\
$\geq 7$ & 2 & + & 100 & + dan - & 50 & + & 100 \\
\hline
\end{tabular}

Berdasarkan hasil tersebut, diketahui BCS berhubungan dengan kecukupan nutrisi sehingga mempengaruhi reproduksi. Sodiq dan
Budiono (2012) BCS dapat digunakan untuk menggevaluasi kecukupan nutrisi dan lemak yang dimiliki induk, sehingga nilai BCS sangat berpengaruh terhadap 
kemunculan estrus. Persentase kebengkakan paling rendah adalah BCS $\geq 7$ diduga akibat penimbunan lemak pada organ reproduksi sehingga produksi hormon estrogen kurang optimal. Prasita et al. (2015) menyatakan bahwa BCS yang terlalu tinggi mengindikasikan bahwa perlemakan pada ternak tersebut tinggi sehingga pada organ reproduksinya juga memiliki timbunan lemak yang mengakibatkan siklus hormonal ternak tersebut terganggu Tahir (2016) menyatakan bahwa intensitas berahi yang lemah akibat pola hormonal terutama estrogen yang terganggu ditandani dengan timbulnya warna merah pada vulva tetapi tidak terjadi bengkak, konsistensi lendir yang tidak kental dan sapi terlihat gelisah tetapi tidak mau di naiki pejantan.

Perubahan warna dan pembengkakan vulva dipengaruhi oleh kadar hormon estrogen yang tinggi pada fase menjelang ovulasi yang memicu hormon adrenalin sehingga tejadi peningkatan aktivitas jantung dan terjadi peningkatan jumlah darah pada pembuluh darah daerah sekitar vulva yang membuat warna vulva menjadi merah dan terjadi bengkak. Siswati (2014) menyatakan bahwa suplai darah pada organ reproduksi yang meningkat akan mengakibatkan vulva membengkak dan memiliki warna merah terang. Suplai darah yang meningkat mengakibatkan sumber energi yang dibawa oleh darah menuju vulva meningkat, akibatnya terjadi peningkatan aktivitas sel sehingga suhu pada vulva meningkat. Menurut Dewi et al. (2011), estradiol dengan kadar yang meningkat akan meningkatkan suplai darah menuju vagina, sehingga aktivitas sel di daerah vagina meningkat yang berdampak warna vulva lebih merah dan meningkatnya temperatur vulva.

\section{Penampakan lendir}

Data penampakan lendir sapi Sapi PO berbagai BCS yang disinkronisasi berahi dengan medroxy progesterone acetat disajikann dalam Tabel 3.

Tabel 3. Modus Penampakan Lendir Berbagai BCS Sapi Yang Berahi

\begin{tabular}{lccc}
\hline BCS & Jumlah sapi & Modus & $\%$ \\
\hline $1-<4$ & 7 & + & 100 \\
$\geq 4-<7$ & 9 & + & 100 \\
$\geq 7$ & 2 & + & 100 \\
\hline
\end{tabular}

\begin{abstract}
Sapi dengan BCS yang baik, bahwa nutrisinya tercukupi akan menampilkan tanda-tanda berahi yang normal seperti halnya pengeluaran lendir, akibat produksi estrogen yang normal. Ratnawati dkk. (2007) menyatakan bahwa pada saat ternak mengalami kekurangan nutrisi maka akan mengakibatkan terhambatnya produksi hormon LH dan
\end{abstract}

FSH yang berakibat pada menurunnya produksi hormon estrogen. Anisa (2016) menyatakan bahwa lendir serviks yang dikeluarkan dipengaruhi oleh estrogen yang membuat hormon adrenalin dan hormon oksitosin disekresikan, hormon oksitosin akan membuat sel endotelium pembuluh darah menjadi permeabel yang meningkatkan aktivitas sel goblet 
sehingga terjadi penimbunan air sehingga tekanan sel goblet tinggi mengakibatkan sel goblet pecah sehingga keluar lendir serviks. Adanya lendir serviks tergantung pada kadar estrogen yang disekresikan oleh masing-masing individu sapi. Suharto (2003) menyatakan bahwa penampakan lendir serviks dipengaruhi oleh perbedaan kadar hormon estrogen pada masing-masing individu saapi.

\section{Ereksi uterus}

Data hasil pengamatan ereksi uterus disajikan dalam Tabel 4.

Tabel 4. Modus Ereksi Uterus Berbagai BCS Sapi Yang Berahi

\begin{tabular}{cccc}
\hline \hline BCS & Jumlah sapi & Modus & $\%$ \\
\hline $1-<4$ & 7 & + & 100 \\
$\geq 4-<7$ & 9 & + & 77,78 \\
$\geq 7$ & 2 & + & 100 \\
\hline
\end{tabular}

Ereksi uterus sapi dengan persentase paling rendah adalah $\mathrm{BCS} \geq 4$ $<7$, karena terdapat 2 ekor induk yang tidak mengalami ereksi uterus. Ereksi uterus merupakan suatu tanda bahwa ternak telah siap untuk dikawinkan. Partodiharjo (1992) menyatakan bahwa ereksi uterus menandakan bahwa ternak sedang mengalami berahi dan sudah siap untuk dikawinkan. BCS $\geq 4-<7$ menandakan bahwa nutrisi telah tercukupi, tetapi endometritis lebih banyak terjadi pada sapi BCS $\geq 4-<7$ (Tabel 1), sehingga diduga menjadi penyebap tidak terjadi ereksi uterus.
Endometritis menyebabkan gangguan pelepasan hormon prostalglandin sehingga ereksi tidak muncul. Menurut Tuasikal et al. (2004) kelainan berahi dapat dipengaruhi oleh endometritis ringan yang dapat menghambat pelepasa hormon prostaglandin yang berfungsi sebagai hormon utama dari uterus.

\section{Kecepatan munculnya berahi}

Data hasil pengamatan kecepatan munculnya berahi pada sapi yang disinkronisasi berahi disajikan dalam Tabel 5.

Tabel 5. Rataan Kecepatan Munculnya Berahi Sapi pada Berbagai Kelompok BCS

\begin{tabular}{ccc}
\hline \hline Kelompok BCS & Jumlah Sapi & Rataan \pm Simpangan Baku \\
\hline $1-<4$ & 7 & $364,6 \pm 117,65$ \\
$\geq 4-<7$ & 9 & $312,89 \pm 118,01$ \\
$\geq 7$ & 2 & $372 \pm 220,62$
\end{tabular}

Tabel 6 menunjukkan bahwa kecepatan berahi antar golongan BCS tidak menunjukkan perbedaan yang nyata. Munculnya berahi paling cepat adalah BCS sedang ( $\geq 4-<7)$. Hasil tersebut lebih lama dari penelitian Arman (2003) yang menujukkan bahwa berahi muncul 24-48 jam setelah spons intra vagina dikeluarkan. Kecukupan nutrisi berhubungan erat dengan BCS sehingga dapat mempengaruhi kecepatan timbulnya berahi, karena nutrisi yang diperoleh digunakan untuk produksi berbagai hormon termasuk hormon reproduksi. Sodiq dan Budiono (2012) BCS dapat digunakan untuk 
menggevaluasi kecukupan nutrisi dan cadangan energy berupa lemak yang dimiliki induk, sehingga nilai BCS sangat berpengaruh terhadap kemunculan estrus. Budiawan et al. (2015) menyatakan bahwa kecukupan nutrisi berperan penting dalam siklus reproduksi, dibutuhkan nutrisi yang cukup untuk produksi LH yang berfungsi merangsang pertumbuhan folikel sehingga dapat terjadi estrus, sehingga jika nutrisi yang kurang berakibat pada kemunculan estrus yang lebih lama. Gangguan pada organ reproduksi juga dapat mempengaruhi produksi hormon reproduksi sehingga estrus menjadi terlambat. Handayani et al. (2014) menyatakan bahwa gangguan reproduksi dapat menurunkan produksi hormon estrogen dan mengakibatkan sapi mengalami keterlambatan estrus.

\section{Lama berahi}

Data hasil pengamatan kecepatan munculnya berahi disajikan dalam Tabel 6.

Tabel 6. Rataan lama berahi berbagai kelompok BCS sapi yang disinkronisasi berahi

\begin{tabular}{ccc}
\hline \hline \multirow{2}{*}{ Kelompok BCS } & \multicolumn{2}{c}{ Tanpa GnRH } \\
\cline { 2 - 3 } & Jumlah Sapi & Rataan \\
\hline $1-<4$ & 7 & $628,71^{\mathrm{A}} \pm 61,432$ \\
$\geq 4-<7$ & 9 & $553^{\mathrm{AB}} \pm 190,19$ \\
$\geq 7$ & 2 & $422^{\mathrm{B}} \pm 121,62$
\end{tabular}

Superkrip dengan huruf besar berbeda pada kolom yang sama menunjukkan adanya perbedaan nyata $(\mathrm{P}<0,05)$. Superkrip dengan huruf besar sama pada kolom yang sama menunjukkan tidak adanya perbedaan nyata $(\mathrm{P}<0,05)$.

Berahi sapi yang dicapai cukup baik, dengan waktu kemunculan berahi paling lama adalah sapi BCS $1-<4$. Perbedaan lama berahi yang terjadi diduga karena ada sapi yang masih dara dan ada yang sudah pernah beranak (Tabel 1) dimana sapi yang pernah beranak akan memiliki lama berahi yang lebih panjang. Darussalam (2016) menyatakan bahwa sapi dara memiliki periode lama berahi yang lebih pendek dari sapi induk. Lama berahi yan lebih pendek pada BCS $\geq 4-<7$ dan $\geq 7$ dibandingkan dengan BCS 1-<4 selain akibat faktor tersebut diatas diduga terjadi karena adanya gangguan pada organ reproduksi akibat kegemukan dengan indikasi BCS tinggi maupun akibat adanya penyakit. Handayani et al. (2014) menyatakan bahwa gangguan reproduksi maupun kekurangan nutrisi akan mempengaruhi produksi hormon estrogen, dimana estrogen sebagai hormon yang menimbulkan gejala berahi. Prasita et al. (2015) menyataan bahwa BCS yang terlalu tinggi mengindikasikan bahwa perlemakan pada ternak tersebut tinggi sehingga pada organ reproduksinya juga memiliki timbunan lemak yang mengakibatkan siklus hormonal pada ternak tersebut terganggu.

\section{KESIMPULAN}

Berdasarkan hasil penelitian dapat disimpulkan bahwa sinkronisasi berahi menggunakan Medroxy Progesteron Acetate tidak memberikan efek yang signifikan pada sapi berbagai kelompok BCS. Beragamnya BCS sapi menampilkan tanda berahi dengan 
intensitas yang hampir sama tetapi BCS sedang memiliki lama berahi lebih baik dari BCS rendah dan tinggi. BCS rendah memiliki kecepatan berahi yang lebih baik dari BCS sedang dan tinggi.

\section{DAFTAR PUSTAKA}

Anisa, E. 2016. Pengaruh Body Condition Score (BCS) Berbeda Terhadap Intensitas Berahi Sapi Induk Simental Peranakan Ongole (Simpo). Fakultas Peternakan dan Pertanian, Universitas Diponegoro, Semarang (Skripsi)

Arman, C. 2003. Sinkronisasi berahi menggunakan susuk progesterone pada sapi Brahman-Cross di pulau Lombok. Seminar Nasional Peternakan dan Veteriner. Puslitbang Peternakan, Bogor 29-30 September 2003.

Badan Pusat Statistik. 2016. Produksi daging menurut provinsi.

Budiawan, A., M. N. Ihsan dan S. Wahjuningsih. 2015. Hubungan body condition score terhadap service per conception dan calving interval sapi potong Peranakan Ongole di Kecamatan Babat Kabupaten Lamongan. J. Ternak Tropika 16 (1): 34-40

Darussalam. 2016. Pengaruh Perlakuan Sinkronisasi Berahi Terhadap Respon Berahi Pada Sapi Bali Induk Pasca Melahirkan. Fakultas Peternakan, Universitas Hasanudin, Makasar. (Skripsi).

Dewi, R.R., Wahyuningsih dan D. T. Widayati. 2011. Respon estrus pada kambing Peranakan Ettawa dengan body condition score 2 dan 3 terhadap kombinasi implant controlled internal drug release jangka pendek dengan injeksi prostaglandin f2 alpha. Jurnal Kedokteran Hewan. 5 (1):11-16.

Handayani, U. F., M. Hartono dan Siswanto. 2014. Respon kecepetan timbbulnya estrus dan lama estrus pada Sapi Bali setelah dua kali pemberian prostaglandin $\mathrm{F} 2 \alpha$ (pgf2 $\alpha$ ). J. Ilmiah Peternakan Terpadu. 2 (1): 33-39

Hardjopranjoto, S. 1995. Ilmu Kemajiran pada Ternak. Airlangga University Press, Surabaya.

Kementan. 2015. Outlook Komoditas Pertanian Subseektor Peternakan Daging Sapi. Pusat Data dan Sistem Informasi Pertanian Secretariat Jendral Peternakan Kementerian Pertanian.

Prasita, D., D. Samsudewa dan E. T. Setiatin. 2015. Hubungan antara Body Condition Score (BCS) dan lingkar panggul terhadap Litter Size Kambing Jawarandu di Kabupaten Pemalang. Agromedia. 33 (2): 6570.

Ratnawati. D., C. P. Wulan., A.S. Lukman. 2007. Petunjuk Teknis Penanganan Gangguan Reproduksi pada Sapi Potong. Pusat Penelitian dan Pengembangan Peternakan. Badan Penelitian dan Pengembangan Pertanian. Departemen Pertanian

Rizal, M. 2005. Pengaruh implementasi progesterone intravaginal terhadap 
timbulnya estrus pada domba Garut betina. J. I. Trop. Anim. Agric. 30 (3) : 167-171

Shinjo, A. 1990. First Course in Statistics, First Edition. University of the Ryukyus Nishihara-Cho, Okinawa

Sodiq, A dan M. Budiono. 2012. Produktivitas sapi potong pada kelompok tani ternak di pedesaan. J. Agripet. 12 (1) : 28-33

Spiegel, M. R. 2004. Schaum's Easy Outline. Erlangga. Jakarta.

Suharto, K. 2003. Penampilan Poensi Reproduksi Sapi Perah Friesian Holstein akibat pemberian kualitas ransum berbeda dan infusi larutan iodium povidon $1 \%$ intra uterin.
Program Pasca Sarjana Universitas Diponegoro. (Thesis Magister Ilmu Ternak).

Tahir, T. 2016. Percepatan Berahi pada Sapi Bali Dara melalui Pemberian Konsentrat dengan Level Protein Berbeda. Fakultas peternakan Universitas Hasanudin. (Skripsi).

Tuasikal, B. J., Totti, T dan Ratnawati, K. 2004. Studi Gangguan Reproduksi Sapi Perah dengan teknik Radio Immunoassay (RIA) Progesteron. Risalah Seminar Ilmiah Penelitian dan Pengembangan Aplikasi lsotop dan Radiasi. Puslitbang Teknik Nuklir, Batan 